the classic thriller The Thirty-Nine Steps.

Along with that huge range of contributions to the war effort, what becomes evident in Secret Warriors is the easy relations between different elements of the elite to which nearly all these scientists and scholars belonged. It is fascinating to see how similar the situation was in both world wars, and how many names appear in accounts of both. At least 13 of the men mentioned by Downing were as familiar in the Second World War as in the first.

The straightforward story Downing tells is a refreshing change from older treatments of science and war, including academic ones. These derived from stories scientists wanted to have told - accounts of the military's indifference to science or biographies of conscience-stricken nuclear physicists. Such arguments have led to a lack of frankness about the actual relationship between science and war; even some literary scholars with an interest in science argue that it was only in the Second World War that science and the military became allied. Historians of science with a little more knowledge have even claimed that there were negligible links between the two before 1914. Downing has done a great service by ignoring these risible theses. The connections are long-standing, deep and important to both, and have been celebrated for centuries.

Downing does well to ignore previous accounts that stress an alleged hostility to new techniques among the British elite - a view that has severely distorted our understanding of the history of British science. But a little declinist mud has stuck to his boots, even when he is contradicted by the evidence that he presents. Thus he laments that the British military academy Sandhurst did not teach science, which might seem damning; but he notes elsewhere in the book that Woolwich, which trained engineers and artillery personnel, did. And although it might seem true that British universities were dominated by pure science and the arts, that is to ignore key points in other parts of the book, such as the importance of Cambridge engineering, or the point that many British universities were, to a significant degree, medical schools. In Britain, as elsewhere in both peace and war, science was and remains deeply connected to the military. What now needs to be explained is why so many intellectuals, especially in the sciences, sought to deny or ignore this.

David Edgerton is Hans Rausing professor of the history of science and technology and of modern British history at King's College London, UK. He is author of England and the Aeroplane. e-mail:david.edgerton@kcl.ac.uk

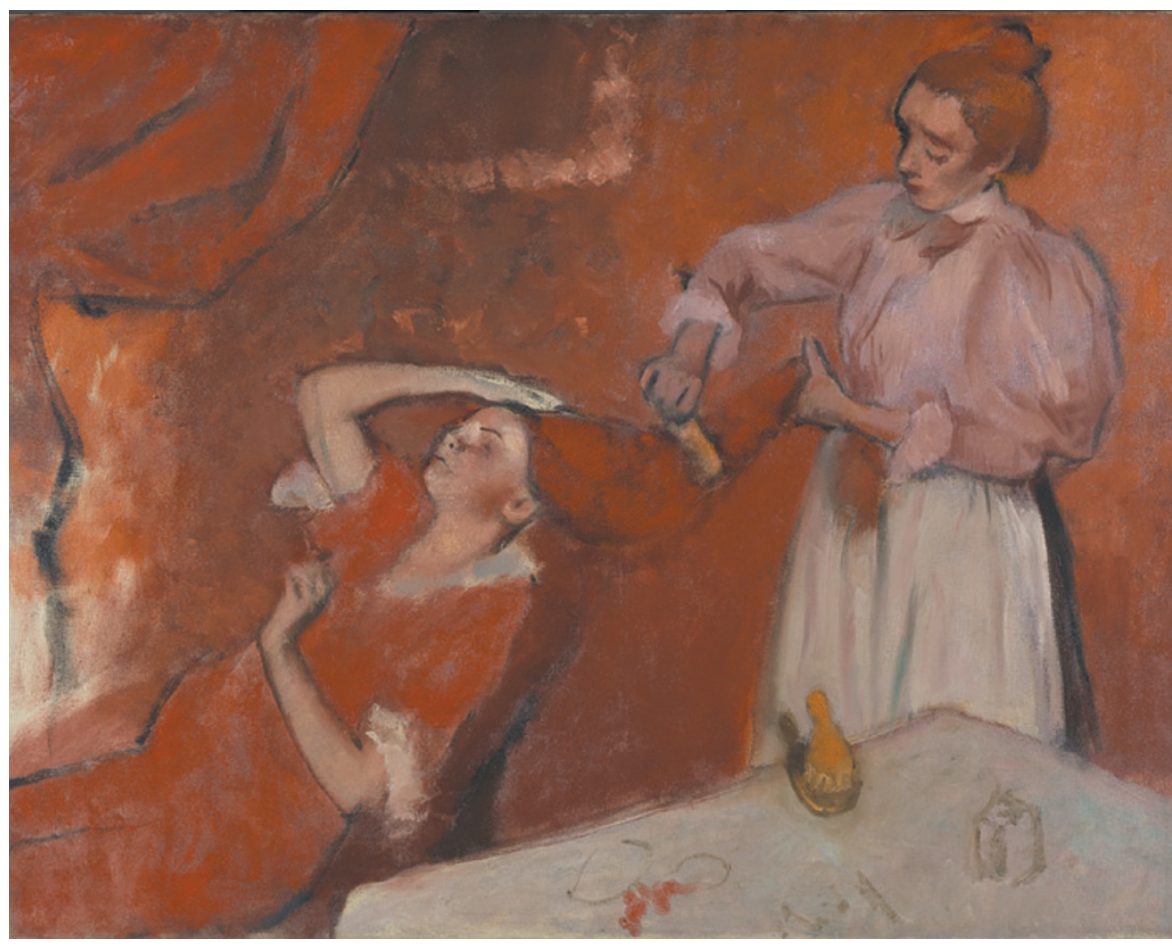

Vermilion, an ancient pigment, features in Edgar Degas' innovative 1896 Combing the Hair.

SCIENCE OF COLOUR

\title{
Hue and eye
}

\section{Barbara Kiser revels in an immersive show revealing the scientific base coat to 700 years of European art.}

$\mathrm{F}$ or millennia, artists chased the blues from Egyptian blue frit to ultramarine, azurite, cobalt blue and indigo. Derived from earthbound minerals, metals and plants, these pigments signalled the celestial, tinting the robes of painted Renaissance Virgins by the score, and the saturated sky behind the meeting of god and mortal in Titian's sixteenth-century masterwork Bacchus and Ariadne. The hunt for blue - and all the other hues - is a tale as bound up in science and technology as in aesthetics and tradition.

That long, complex quest is chronicled in Making Colour at London's National Gallery. The show peers into the luminous slicks of paint in a Monet or a Memling to reveal the chemical and physical traits of the pigments and their origins. In rooms devoted to blue, green, yellow, red, purple, and gold and silver, exemplary paintings are set next to raw materials and the pigments derived from them. Alongside are manufactured objects glazed or dyed with the same colourants, pointing to the fact that up to the nineteenth century, many pigments were by-products of dye manufacture, metallurgy and other industries.

"We are trying to tell the history of materials in European painting in very visual form,"

\section{Making Colour}

The National Gallery, London.

Until 7 September 2014. has analysed the collection - spanning key schools of European art from the fourteenth to the nineteenth centuries. Over much of that time, artists "needed spectrally powerful colours for their paintings, particularly for the often brilliantly coloured robes of religious figures", notes Roy.

A vast sunburst of colour presides at the start of the show - the 72-colour 'chromatic diagram' devised in 1839 by chemist Michel Eugène Chevreul as a way of thinking about complementary colours. Nearby is Vincent Van Gogh's Two Crabs (1889), an electric contrast of hot reds and acid greens that testifies to Chevreul's influence. A cluster of other colour wheels includes that of Johann Wolfgang von Goethe. The German polymath's ideas on colour were muddled, but they opened the way to Chevreul's and influenced J. M. W. Turner, whose palette, smeared with a muddy impasto of russets and greens, is showcased across the room.

Beyond, the near-black walls give a 
chromatic intensity to the paintings and objects. Another kind of intensity lies in what it took to acquire, transport and process some pigments. The 'blue room' features a vast photo of an Afghan miner lugging a toddlersized chunk of lapis lazuli - the source of the mineral lazurite, from which natural ultramarine was derived. From around 1200 to the nineteenth century, European painters imported lapis lazuli from the remote Sar-eSang mines in what is now Afghanistan, by way of Baghdad, Damascus, Cyprus and Italian ports. The extraction of the pigment, a chore involving lye, wax and plenty of elbow grease, failed to deter artists eager for strong blues and the cachet of costliness.

Thomas Gainsborough's 1785 portrait of theatre diva Sarah Siddons in a blue-striped dress marks how chemical experimentation provided an alternative: Prussian blue. Around 1704, the Berlin alchemist and colour-maker Diesbach was attempting to make red 'lake' pigment using potash, iron sulphate and a decoction of dried cochineal beetles. The potash, however, was contaminated with 'animal oil' derived from blood, and the result was a deep blue - one of the first modern synthesized pigments.

Pigments that were spin-offs from industry are showcased by a traverse through yellow. The mustard tint on the robe of a majolica (glazed terracotta) angel by the Renaissance Della Robbia workshop is

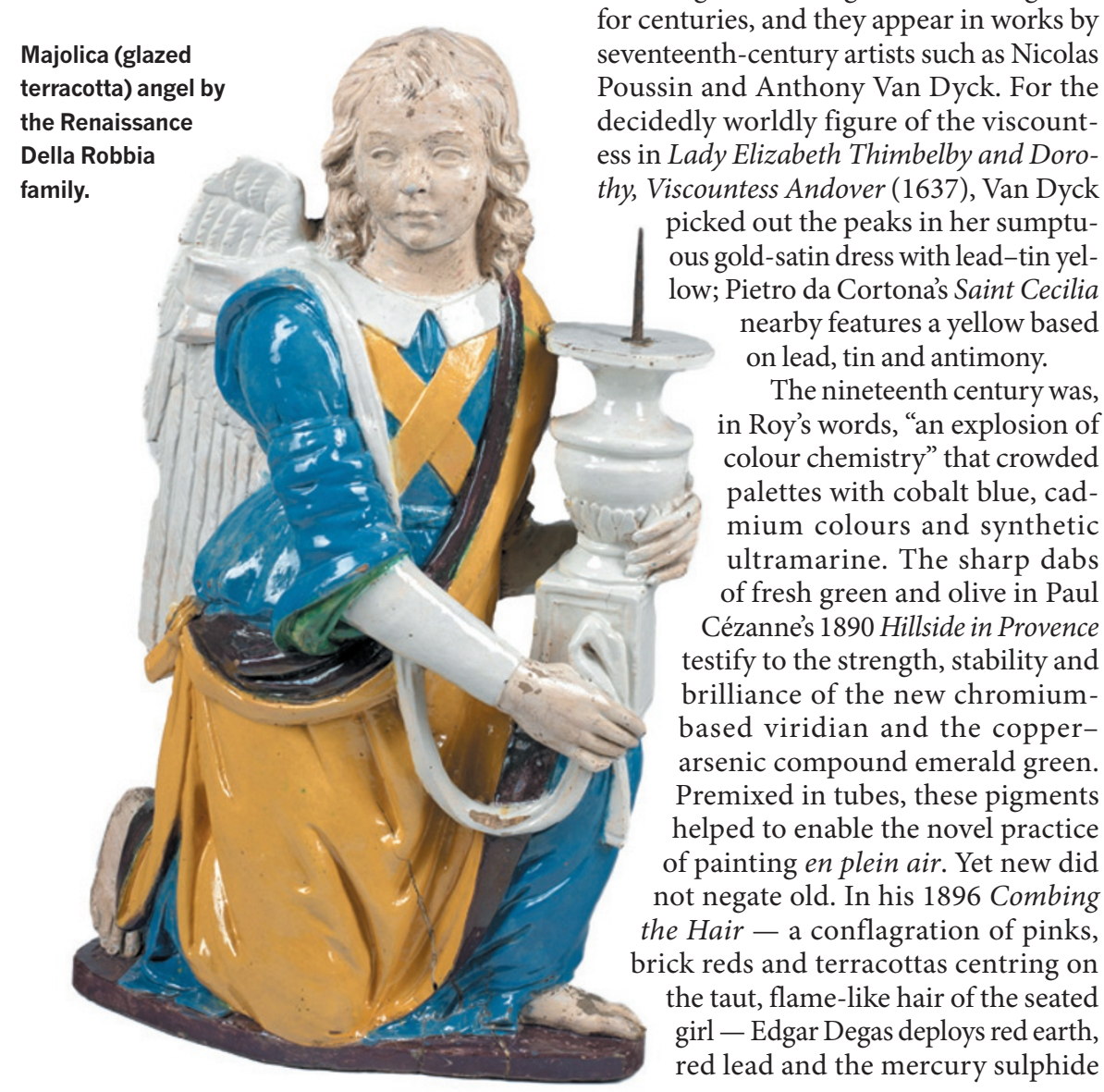

based on a lead and antimony colourant - a family of yellows that sometimes also incorporates tin. These stable oxides have been used in glass-making and ceramic glazes for centuries, and they appear in works by seventeenth-century artists such as Nicolas Poussin and Anthony Van Dyck. For the decidedly worldly figure of the viscountess in Lady Elizabeth Thimbelby and Doroy, Viscountess Andover (1637), Van Dyck picked out the peaks in her sumptuous gold-satin dress with lead-tin yeletro da Cortona's Saint Cecilia The nineteenth century was, Roy's words, "an explosion of colour chemistry" that crowded palettes with cobalt blue, cadmium colours and synthetic ultramarine. The sharp dabs of fresh green and olive in Paul Cézanne's 1890 Hillside in Provence testify to the strength, stability and brilliance of the new chromiumbased viridian and the copperarsenic compound emerald green. Premixed in tubes, these pigments helped to enable the novel practice of painting en plein air. Yet new did not negate old. In his 1896 Combing the Hair - a conflagration of pinks, ick reds and terracottas centring on (a) seated red lead and the mercury sulphide
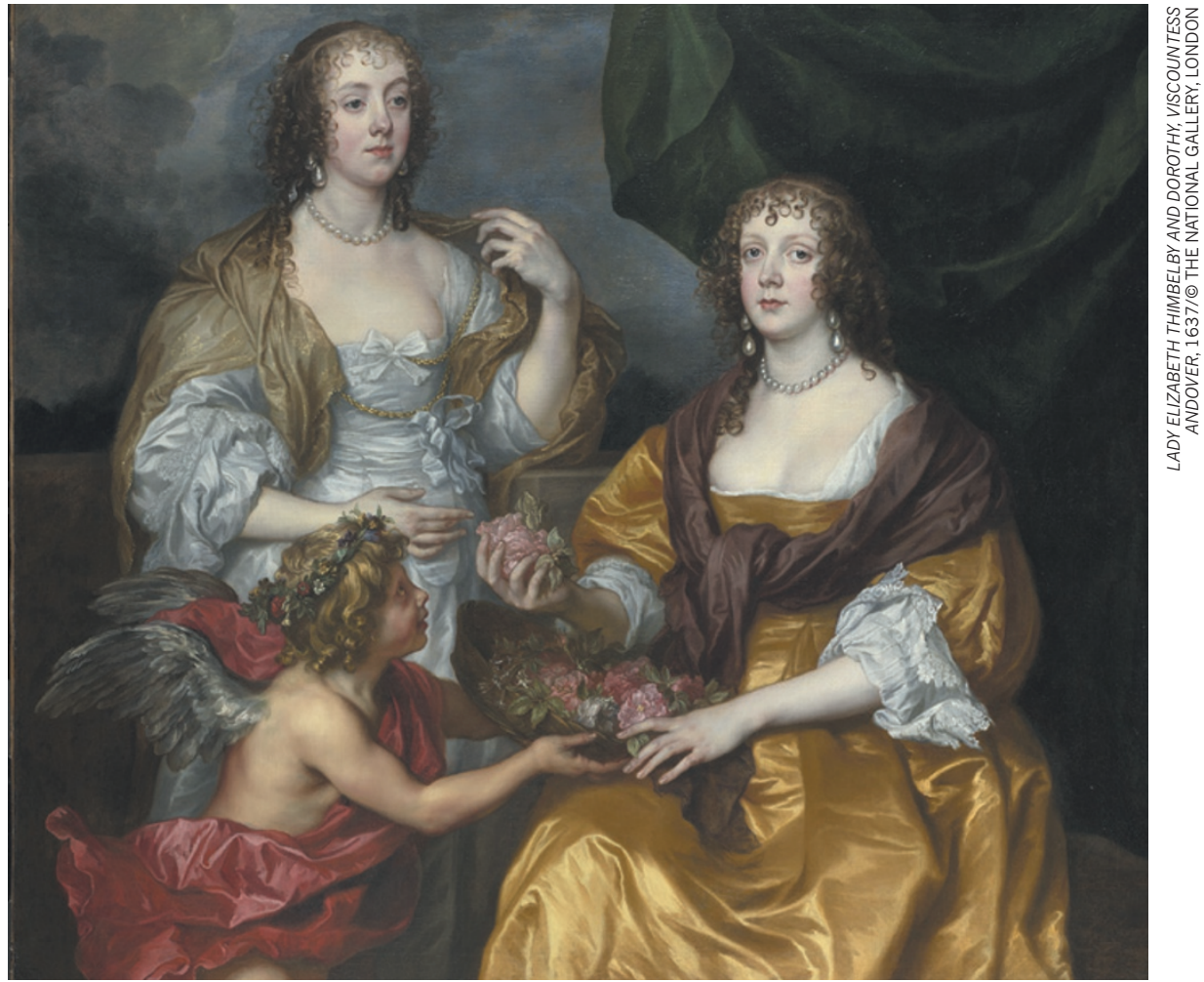

A family of yellow pigments highlight a gown in Anthony Van Dyck's portrait, and an angel's robe (below).

vermilion. This last has been used in painting, first as the natural mineral cinnabar and then in a synthetic form, for millennia.

The chromatic trail of primary and secondary colours comes to a halt in a welter of metallics. Giovanni Girolamo Savoldo's sixteenth-century Mary Magdalene almost steals the show, even though the silvery hue of her cloak is a beautiful illusion crafted in lead white and lamp black. That every hue you have seen here is a dance between wavelengths of electromagnetic radiation, the optic nerve and the brain is left for last (and for more on this and many topics featured in the show, see Philip Ball's excellent Bright Earth; University of Chicago Press, 2001). On the way out of the exhibition, a wellcrafted film on human perception awaits, including a crowd-sourced experiment. Created by neuroscientist Anya Hurlbert and backed by the London-based Wellcome Trust, this examines colour constancy (how we perceive colours as the same in different lights) by inviting visitors to assess two reproductions of a Cézanne still life under varying illumination.

But at base, Making Colour ushers us into a materials world. Beyond the artists' transformation of coloured earth or ground resin into luminous windows on lost worlds is a broader transformation in chemistry, exploration and commerce - a necessary underlay to the aesthetic urge.

Barbara Kiser is Nature's Books and Arts editor. 